Personalidade Acadêmica Homenageada:

Augustus B. Cochran III (Agnes Scott College)

\title{
INCORPORAÇÕES IMOBILIÁRIAS: A IMPORTÂNCIA DOS INSTRUMENTOS PÚBLICOS PARA A ESTABILIDADE DO COMÉRCIO DE IMÓVEIS NA PLANTA
}

\section{REAL ESTATE INCORPORATIONS: THE IMPORTANCE OF PUBLIC INSTRUMENTS FOR THE STABILITY OF REAL ESTATE TRADE}

FERNANDA COSTA

Mestre em Direito pela Universidade de Marília - UNIMAR. Marília - SP. Aluna especial do Curso de Mestrado em Direito Empresarial e Cidadania do Centro Universitário de Curitiba - UNICURITIBA. Curitiba - PR. Tabeliã. E-mail: nanda8143@hotmail.com

\section{ELEANDRO COSTA}

Mestre em Direito pela Universidade de Marília - UNIMAR. Marília - SP. Doutorando em Direito pela Universidade de Marília - UNIMAR. Marília - SP. Tabelião. E-mail: granja8519@gmail.com

\section{RESUMO}

As incorporações imobiliárias são iniciativas de grande relevância econômica e social, daí a importância prática do tema. O objetivo da incorporação imobiliária é a construção de um condomínio edilício de grande porte, com capital inicial advindo de contratos de promessa de compra e venda de unidades imobiliárias do edifício. $O$ sucesso do empreendimento depende da estabilidade dessas contratações preliminares. Para tal, além da idoneidade das partes, é fundamental a higidez jurídica dos instrumentos contratuais. A venda dessas unidades imobiliárias "na planta" é realizada, portanto, por meio de contrato preliminar, cujo objeto não é o bem imóvel, 
Personalidade Acadêmica Homenageada:

Augustus B. Cochran III (Agnes Scott College)

mas a vontade a ser declarada em futura escritura pública de compra e venda, que configura o contrato definitivo. Atualmente, as incorporações são regulamentadas concomitantemente pelo Código Civil e pela Lei n. 4.591/1964 (Lei das Incorporações), com uma série de requisitos específicos. Embora não seja de uso legalmente obrigatório, o instrumento público (escritura pública) é altamente recomendável para a realização de promessas de compra e venda de imóveis na planta, visto que a satisfação dos interesses individuais depende do sucesso do empreendimento como um todo. Diante disso, verifica-se que a atuação de um tabelião pode ser fundamental para o alcance do objetivo final do negócio entabulado. O tabelião é profissional do direito, dotado de fé pública, tecnicidade e imparcialidade, a quem o Estado confia o exercício o múnus público de analisar contratações e conformar a vontade das partes. A natureza das incorporações imobiliárias justifica os custos do instrumento público. Trata-se de uma ação economicamente racional, revelando a profissionalidade e a prudência que se espera do empreendedor imobiliário envolvido em negócios de elevado valor pecuniário. Além disso, cria possibilidades de relações jurídicas mais confiáveis. Assim sendo, a interferência do notário e sua qualificação notarial, diante da complexidade das incorporações e das graves consequências que a caducidade dessas negociações pode gerar para todos os envolvidos, confere estabilidade às avenças, contribuindo para o sucesso final do empreendimento, garantindo segurança àqueles que transacionam nesse mercado. $A$ metodologia utilizada no presente trabalho foi baseada em pesquisas de material bibliográfico, revistas impressas e eletrônicas, bem como na legislação nacional.

PALAVRAS-CHAVE: Incorporação imobiliária, Promessa de compra e venda, Contrato Preliminar, Instrumento Público.

\section{REFERÊNCIAS}

BDINE JÚNIOR, Hamid Charaf. Compromisso de compra e venda em face do código civil de 2002: contrato preliminar e adjudicação compulsória. Doutrinas Essenciais de Direito Registral, vol 3, p. 819-856, dez/2011. 
Personalidade Acadêmica Homenageada:

Augustus B. Cochran III (Agnes Scott College)

BRANDELLI, Leonardo. A Função Notarial na Atualidade. Revista de Direito Imobiliário, vol. 80/2016, p. 55-78, Jan-Jun/2016.

Atuação notarial em uma economia de mercado. A tutela do hipossuficiente. Doutrinas Essenciais de Direito Registral, vol. 7/2013, p. 575-625, Set/2013.

. Teoria geral do Direito Notarial. 4 ed. São Paulo: Saraiva, 2011.

BRASIL. Superior Tribunal de Justiça (Terceira Turma). Recurso especial no 1.490.802. Brasília (DF), Superior Tribunal de Justiça, 24 abr 2018 Disponível em: https://ww2.stj.jus.br/processo/pesquisa/?termo $=1490802 \&$ aplicacao $=$ processos.ea\& tipoPesquisa=tipoPesquisaGenerica\&chkordem=DESC\&chkMorto=MORTO. Acesso em 30/03/2019.

BUENO, Sérgio de Godoy. Contrato preliminar. Doutrinas essenciais de direito registral, vol. 4, p. 283-300, jun/2011.

CEF. Imóveis na Planta: linha de crédito destinada à construção de empreendimentos imobiliários. Disponível em: http://www.caixa.gov.br/empresa/credito-financiamento/imoveis/financiamento-paraproducao-imoveis/imovel-na-planta/Paginas/default.aspx. Acesso em: 30/04/2019.

CHALHUB, Melhim Namem. A promessa de compra e venda no contexto da incorporação imobiliária e os efeitos do desfazimento do contrato. Revista de Direito Civil Contemporâneo, vol. 7/2016, p. 147-183, Abr-Jun/2016.

. Incorporação imobiliária: aspectos do sistema de proteção do adquirente de imóveis. Revista de Direito Imobiliário. vol. 75/2013, p. 167, Jul-Dez/2013.

CONTADIN, Éder Augusto. O contrato preliminar e sua inserção no código civil brasileiro. Revista de direito privado, vol. 56, p. 227-261, out-dez/2013.

DIP, Ricardo H. M. Sobre a Qualificação no Registro de Imóveis. Doutrinas Essenciais de Direito Registral, vol. 6, p. 933-985, Dez/ 2011.

FIGUEIREDO, Luiz Augusto Haddad. Condomínio de lotes: o novo regime jurídico da lei 13.465/2017. Revista de Direito Imobiliário. vol. 85/2018, p. 47-83, Jul-Dez/2018.

HÖHN, Christiane Scabell; SIQUEIRA, Maina Maria Novello. A responsabilidade nas incorporações imobiliárias. Revista Jurídica Consulex. Disponível em: https://www.bmalaw.com.br/arquivos/Artigos/CSH-Maina.pdf. Acesso em: 30/04/2019.

KFOURI NETO, Miguel; TAVARNARO, Roberto Ribas. A boa-fé objetiva nos contratos de medicina pré-paga. Revista Jurídica UNICURITIBA, vol. 4, n. 45, p. 808-831, 2016. 
Personalidade Acadêmica Homenageada:

Augustus B. Cochran III (Agnes Scott College)

MOTTA, Sandro da. Comprar imóvel na planta é um bom negócio?. Disponível em: https://exame.abril.com.br/seu-dinheiro/comprar-imovel-na-planta-e-bom-negocio/. Acesso em: 30/04/2019.

OLIVEIRA, Jane Resina F. de. Breves considerações sobre incorporações imobiliárias. Disponível em: https://www.migalhas.com.br/dePeso/16,Ml101237,21048-

Breves+consideracoes+sobre+incorporacoes+imobiliarias. Acesso em: 30/04/2019.

PROMESSA DE COMPRA E VENDA, mesmo sem registro, gera efeitos, diz STJ, Conjur, 10 mai 2018. Disponível em: https://www.conjur.com.br/2018-mai10/promessa-compra-venda-mesmo-registro-gera-efeitos. Acesso em 29/03/2019.

SERPA LOPES, Miguel Maria. Promessa de compra e venda de bens imóveis. Doutrinas essenciais de direito registral, vol. 3, p. 941-948, dez/2011.

TRISTÃO, Eduardo. Compromisso de compra e venda: contribuições para o estudo de sua natureza jurídica. Doutrinas essenciais de direito registral, vol. 3, p. 747793, Dez/2011.

URBANO, Hugo E. M. C. A eficácia externa dos contratos e a responsabilidade civil de terceiros. Doutrinas Essenciais Obrigações e Contratos, vol. 3, p. 1053-1100, Jun/2011.

VASCONCELOS, Pedro Pais. Direito Comercial. Coimbra: Almedina, 2011. 